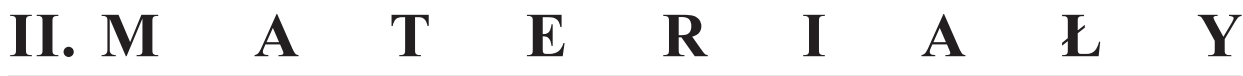

DOI: $10.19195 / 0080-3626.61 .12$

TOMASZ DZIURDZIA

\section{PROJEKT USTAWY O KSIĄŻCE Z 2015 ROKU}

Głosy o potrzebie wprowadzenia w Polsce stałej ceny książek podnoszone były w środowisku wydawniczym i księgarskim od początku XXI wieku, w celu ochrony tradycyjnych księgarń przed konkurencją dużych sieci księgarskich, supermarketów oraz sprzedawców internetowych, dysponujących znacznie większymi możliwościami obniżania cen detalicznych. W odróżnieniu bowiem od systemu wolnych cen książki, w którym sprzedawcy końcowi mają swobodę w decydowaniu o cenach książek, system stałej (jednolitej, sztywnej) ceny książki zobowiązuje ich do stosowania ceny ustalonej przez wydawcę, ograniczając lub całkowicie uniemożliwiając prowadzenie konkurencji cenowej podczas sprzedaży detalicznej konkretnej pozycji. Główną wspólną cechą systemu stałych cen jest ustalenie tzw. okresu ochronnego, który obowiązuje przez pewien czas po wprowadzeniu książki na rynek. W trakcie jego trwania zostaje ograniczona możliwość sprzedawców do decydowania o cenie książki, lecz zwykle dopuszcza się udzielanie rabatu w wysokości od 5 do $15 \%$ ceny katalogowej. Długość okresu ochronnego jest różna, najkrótszy to 6 miesięcy, najdłuższy - 24 miesiące od wydania książki. Po jego upływie sprzedawca końcowy nie musi stosować się do ceny ustalonej przez wydawcę. Oczywiście mimo takich obostrzeń jednolita cena detaliczna tego samego tytułu nie zapewnia wszystkim sprzedawcom takich samych zysków. Wynika to z tego, że cena kupna przez detalistów od wydawcy lub hurtownika jest ustalana indywidualnie i nie jest objęta regulacją, co skutkuje różnymi marżami handlowymi ${ }^{1}$.

W przyjętej w różnych państwach na świecie praktyce ustanowienie stałej ceny książek realizowane było bądź na podstawie uregulowań prawnych, bądź

1 R. Mendruń, Stała czy wolna cena na rynku książki?, [w:] A. Guillet-Malik et al., Ustawa o ksiażce. Za i przeciw, Warszawa 2007, passim; M. Appelman, Fixed Book Price, [w:] A Handbook of Cultural Economics, pod red. R. Towse, Cheltenham 2003, s. 237-238; Global Fixed Book Price Report, International Publishers Association, 24.05.2014, s. 1, http://www.internationalpublishers.org/images/reports/2014/fixed-book-price-report-2014.pdf [dostęp: 20.09.2017]. 
na podstawie porozumień zawieranych między wydawcami i sprzedawcami detalicznymi. Spośród państw Unii Europejskiej przepisy o stałej cenie obowiązują w Hiszpanii (od 1975 roku), Francji (1981), Portugalii (1996), Grecji (1997), Austrii (2000), Włoszech (2001), Niemczech (2002), Holandii (2005)² i Słowenii (2014)3. Polski rynek w tej kwestii nie był objęty ustawową regulacją, a zawierania porozumień między wydawcami i sprzedawcami o utrzymaniu stałej ceny książek nie dopuszczało obowiązujące prawo o konkurencji ${ }^{4}$.

$\mathrm{W}$ ostatnich latach w prowadzonej na ten temat dyskusji główna rola przypadła Polskiej Izbie Książki (PIK), jako organizacji zrzeszającej podmioty działające na polskim rynku książki, do której statutowych zadań należy m.in. „reprezentowanie i ochrona interesów gospodarczych jej członków, współtworzenie warunków rozwoju życia gospodarczego w zakresie działalności prowadzonej na rynku książki i działanie na rzecz kształtowania dobrych obyczajów we współdziałaniu Członków Izby oraz na całym rynku książki"5. Członkowie PIK w 2005 roku opowiedzieli się przeciwko zaproponowanej wtedy ustawie o książce, jednak podczas Walnego Zgromadzenia w maju 2010 roku zdecydowali się podjąć działania, by uregulować polski rynek książkí.

Założenia ustawy o jednolitej cenie książki zostały zaprezentowane podczas Walnego Zgromadzenia Członków PIK w listopadzie 2010 roku. Wskazano, że nałożenie na wszystkich sprzedawców obowiązku stosowania jednej ceny ułatwi księgarniom tradycyjnym konkurencję z sieciami księgarskimi i supermarketami, które sprzedają książki, udzielając znacznie większych rabatów, jednak ograniczają swoją ofertę do najlepiej sprzedających się tytułów. Przewidywano, że gdy zakończona zostanie konkurencja cenowa, klienci znacznie częściej będą dokonywali zakupu książek w księgarniach tradycyjnych, które zwiększony dochód będą mogły przeznaczyć na poszerzenie asortymentu i jego promocję. Ponadto będzie to przeciwdziałało budowaniu coraz silniejszej pozycji niewielkiej liczby sprzedawców, co wpłynie również na sytuację wydawców, gdyż pozwoli im wynegocjować korzystniejsze warunki umów?

${ }^{2}$ H. Rønning et al., Books - At what price? Report on policy instruments in the publishing industry in Europe, 15.02.2012, s. 27-28, http://www.europeanbooksellers.eu/wp-content/uploads/2015/03/Books-at-which-Price.pdf [dostęp: 20.09.2017].

3 Global Fixed Book Price Report..., s. 4.

4 J. Włodarczyk, UOKiK przeciwko wprowadzaniu cen detalicznych na ksiażki, Wirtualny Wydawca [portal], 30.06.2004, http://wirtualnywydawca.pl/2004/06/13479 [dostęp: 20.09.2017].

5 Statut Polskiej Izby Książki, PIK [serwis internetowy], 15.05.2013, http://www.pik.org.pl/ upload/files/PIK\%20statut\%20WZ\%2015.05.13.pdf [dostęp: 20.09.2017].

6 Ł. Gołębiewski, P. Waszczyk, Rynek książki w Polsce 2015. Dystrybucja, Warszawa 2016, s. $38-39$.

7 Ł. Gołębiewski, K. Frołow, P. Waszczyk, Rynek książki w Polsce 2011. Dystrybucja, Wrocław 2011, s. 126-136. 
Podczas dyskusji branżowych wokół tworzonej ustawy o książce 10 października 2013 roku PIK umieściła na swojej stronie internetowej materiały poświęcone księgarniom indywidualnym, które zostały opracowane przez Bibliotekę Analiz ${ }^{8}$. Zdaniem autorów opracowania księgarnie niezależne pełnią ważną rolę kulturalną w lokalnych społecznościach i stanowią niezbędną alternatywę dla sieci księgarskich i sprzedaży w Internecie, jednak ich udział w sprzedaży detalicznej książek spada. Udział księgarń niezależnych w sprzedaży detalicznej książek wynosił w tym czasie 15\%, podczas gdy w 1995 roku stanowił 45\%. Przedstawiono kilka czynników szkodzących ich pozycji, przede wszystkim niski poziom czytelnictwa w Polsce (według badań Instytutu Książki i Czytelnictwa Biblioteki Narodowej nastąpił wyraźny spadek w ostatnich latach, a od 2008 roku liczba deklarujących przeczytanie przynajmniej jednej książki nie przekracza połowy badanych ${ }^{9}$ ). W opracowaniu wymieniono również brak promocji czytelnictwa w mediach oraz konkurencję ze strony sieci księgarskich, marketów i sprzedawców internetowych. Jednolita cena książki została wymieniona jako jedna z metod wsparcia księgarń niezależnych, gdyż po zakończeniu konkurencji cenowej, którą dotąd wygrywały sieci księgarskie i markety, to właśnie one miałyby być częściej wybierane przez czytelników $^{10}$.

22 października 2013 roku PIK na swojej stronie zamieściła komunikat dotyczący tworzonej ustawy o książce. Wskazywano w nim na zły stan polskiego rynku książki, zwłaszcza na sytuację księgarń. Zgodnie z przedstawionymi danymi Biblioteki Analiz w 2010 roku było ich 2450, natomiast w 2012 ich liczba spadła do 1800. Argumentowano, że jednolita cena książki będzie stanowiła wsparcie zarówno dla małych księgarń, jak i wydawnictw, które zwiększone zyski przeznaczą na wzbogacenie oferty wydawniczej.

Oprócz tego PIK uzasadniała wprowadzenie regulacji niskim poziomem czytelnictwa w Polsce. W komunikacie pojawiło się sformułowanie: „Celem ustawy jest zwiększenie poziomu czytelnictwa poprzez zapewnienie powszechnego dostępu do książki na terenie całego kraju i urozmaicenie oferty wydawniczej"11. Zdaniem Renka Mendrunia, zajmującego się od kilku lat tematyką jednolitej ceny

${ }^{8}$ Biblioteka Analiz jest firmą zajmującą się badaniami rynku księgarskiego i wydawniczego — zob. O nas, Rynek Książki [portal], http://rynek-ksiazki.pl/o-nas [dostęp: 20.09.2017].

9 D. Michalak, I. Koryś, J. Kopeć, Stan czytelnictwa w Polsce w 2015 roku: wstępne wyniki, Warszawa 2016, s. 12-13, http://ksiegarnia.bn.org.pl/pdf/Stan\%20czytelnictwa\%20w\%20Polsce\%20w\%202015\%20r..pdf [dostęp: 20.09.2017].

10 Księgarnie niezależne - czy sa potrzebne? Materiat do dyskusji inicjowanej przez Polska Izbę Książki, PIK [serwis internetowy], 11.10.2013, http://www.pik.org.pl/komunikaty/88/ksiegarnie-niezalezne-czy-sa-potrzebne [dostęp: 20.09.2017].

11 [Ustawa o Książce - podstawowe założenia i przyczyny wprowadzenia], PIK [serwis internetowy] 22.10.2013, https://web.archive.org/web/20131026111052/http://www.pik.org.pl/ komunikaty,Ustawa_o_Ksiazce_podstawowe_zalozenia_i_przyczyny_wprowadzenia.html [dostęp: 20.09.2017]. 
książki, podniesienie poziomu czytelnictwa nie jest powodem, dla którego podobne regulacje były wprowadzane w innych krajach, a wyniki badań ekonomicznych nie dają podstaw do takiej argumentacji12. Później PIK nie odnosiła się już bezpośrednio do potencjalnego wzrostu czytelnictwa, lecz dalej powoływała się na argumenty zazwyczaj przytaczane przez zwolenników jednolitej ceny książki, z uwzględnieniem sytuacji na polskim rynku książki. Dotyczyły one głównie potrzeby wspierania księgarń niezależnych jako kanałów dystrybucji wartościowej produkcji wydawniczej.

20 lutego 2014 roku PIK zorganizowała konferencję „Na ratunek książkom! Projekt ustawy o jednolitej cenie książek". Przedstawiła wtedy przygotowywany przez siebie projekt przepisów. Opublikowała go na swojej stronie wraz z raportem poświęconym polskiemu rynkowi książki przygotowanym przez Bibliotekę Analiz $^{13}$. W raporcie tym po raz kolejny została podkreślona ważna rola księgarń niezależnych. Wskazano, że oferują klientom rady dotyczące wyboru książki spośród szerokiego asortymentu dostępnego na miejscu, pozwalają też na obejrzenie oferty wydawniczej, co zasadniczo nie jest możliwe podczas zakupów przez Internet, a dodatkowo coraz częściej organizują istotne dla lokalnej kultury spotkania autorskie czy czytelnicze. Mimo to przegrywają konkurencję cenową z innymi sprzedawcami, którzy są w stanie uzyskać od wydawców i dystrybutorów większe rabaty lub sprzedają książki z minimalną marżą handlową. Zamknięcie lokalnych księgarń ma spowodować, że zakup książki będzie możliwy tylko przez Internet, co, jak stwierdzono w raporcie Biblioteki Analiz, może doprowadzić do wejścia na polski rynek „globalnej korporacji”"14 i zmonopolizowania go. Zwrócono przy tym uwagę, że polskie biblioteki publiczne w porównaniu z innymi krajami Europy kupują niewielką liczbę nowości wydawniczych i na obecnym poziomie finansowania nie będą w stanie zaspokoić miejscowego zapotrzebowania na książki ${ }^{15}$.

W opracowaniu Biblioteki Analiz przedstawione zostały także wyniki ankiety przeprowadzonej przez PIK wśród polskich wydawców w 2013 roku. Jej wyniki

12 R. Mendruń, Ustawa o książce w Polsce. Skoro sa za, musza być przeciw, Narodowe Centrum Kultury [serwis internetowy], 29.10.2013, http://nck.pl/badania/aktualnosci/renek-mendrun-ustawa-o-ksiazce-w-polsce-skoro-sa-za-musza-byc-przeciw [dostęp: 20.09.2017].

13 „Na ratunek ksiązkom! Projekt ustawy o jednolitej cenie ksiażek” - materiaty po konferencji 20.02.2014 r., PIK [serwis internetowy], 21.02.2014, http://www.pik.org.pl/komunikaty/153/na-ratunek-ksiazkom-projekt-ustawy-o-jednolitej-cenie-ksiazek-materialy-po-konferencji-20022014-r [dostęp: 20.09.2017].

14 Nie została wymieniona jej nazwa, jednak w tym kontekście przedstawiciele PIK mówią o firmie Amazon - zob. P. Dobrołęcki, Amazon i sprawa polska. Czy bać się wejścia smoka?, Rynek Książki [portal], 26.11.2013, https://rynek-ksiazki.pl/biblioteka-analiz_1/wydanie_447/ amazon-i-sprawa-polska_36433.html [dostęp: 20.09.2017].

15 P. Dobrołęcki et al., Polski Rynek Książki. Szanse i zagrożenia — konieczność zmian, Warszawa 2014, s. 3-5, http://www.pik.org.pl/upload/files/LANG_-_BA_-_Ustawa_o_jednolitej_cenie_21_1.pdf [dostęp: 20.09.2017]. 
świadczyły o tym, że również wydawcy potrzebują wprowadzenia ustawy o jednolitej cenie książek. 10\% uczestników jako czynniki wpływające negatywnie na stan rynku wydawniczego wskazało ,[n]adpodaż na rynku »Taniej książki«", a 8\% — „,nieustanne wyprzedaże przeprowadzane przez niektóre podmioty”, czyli zjawiska, którym regulacje cen mają przeciwdziałać. Jedynie $2 \%$ respondentów bezpośrednio wskazało brak ustawy o książce jako przyczynę problemów polskiego rynku. Niemniej jednak na pytanie o działania, które należałoby podjąć w celu poprawy sytuacji, najwięcej uczestników (21\%) wskazało wznowienie prac nad wprowadzeniem ustawy ${ }^{16}$.

Rada PIK zdecydowała o rozpoczęciu prac nad przepisami regulującymi polski rynek książki w kwietniu 2013 roku. Przygotowanie projektu aktu prawnego zlecono kancelarii Leśnodorski, Ślusarek i Wspólnicy (LSW) ${ }^{17}$. PIK apelowała do swoich członków o wsparcie finansowe prac nad przygotowaniem ustawy oraz działań mających na celu jej wypromowanie i wprowadzenie. We wrześniu 2013 roku został utworzony fundusz celowy dla pokrycia wydatków związanych z realizacją całego przedsięwzięcia, obejmujących koszt kancelarii prawniczej i prowadzenia lobbingu ${ }^{18}$. Łączny koszt na następne 12 miesięcy wyceniono na 90 tysięcy $\mathrm{zf}^{19}$.

Od maja 2013 do lutego 2014 z inicjatywy PIK odbywały się rozmowy z przedstawicielami środowisk wydawców, hurtowników, księgarzy i bibliotekarzy, z którymi konsultowano treść przygotowywanej ustawy. Szczegółowe informacje o przebiegu tych konsultacji nie są jednak znane, gdyż większość spotkań nie została dobrze udokumentowana ${ }^{20}$. Wiadomo z całą pewnością, że autorem kształtu projektu ustawy był adwokat Maciej Ślusarek z kancelarii LSW ${ }^{21}$. Oprócz projektu ustawy sporządził również opinie prawne o zgodności proponowanych

16 Ibidem, s. 7.

17 Projekt Ustawy o ksiażce, PIK [serwis internetowy], 28.07.2016, http://www.pik.org.pl/ pages/47/projekt-ustawy-o-ksiazce [dostęp: 20.09.2017].

$18 \mathrm{~W}$ jego ramach uruchomiona została kampania \#ocalksiążki przygotowana przez firmę Hill+Knowlton Strategies, której zadaniem było przedstawienie opinii publicznej oczekiwanych korzyści wynikających z przyjęcia ustawy oraz głosów poparcia wyrażanych przez współczesnych polskich pisarzy. Kampania prowadzona była na własnej stronie oraz w serwisach społecznościowych Facebook oraz Twitter - zob. \#Ocalksiażki, Hill+Knowlton Strategies [serwis internetowy], 9.02.2017, http://blog.hkstrategies.pl/case-studies/ocalksiazki [dostęp: 20.09.2017].

19 Apel: Fundusz celowy PIK dla projektu „Ustawa o jednolitej cenie książki”, PIK [serwis internetowy], 2.09.2013, http://www.pik.org.pl/komunikaty/156/apel-fundusz-celowy-pik-dla-projektu-ustawa-o-jednolitej-cenie-ksiazki [dostęp: 20.09.2017].

20 Wydarzenia $w$ ramach projektu Ustawy o ksiażce, PIK [serwis internetowy], http:// www.pik.org.pl/upload/files/Wydarzenia\%20w\%20ramach\%20projektu\%20Ustawy $\% 200 \% 20$ ksi\%C4\%85\%C5\%BCce.docx [dostęp: 20.09.2017].

21 „Na ratunek ksią̇̇kom! Projekt ustawy o jednolitej cenie książek”... 
regulacji z prawem Unii Europejskiej ${ }^{22}$ oraz z Konstytucją Rzeczypospolitej Polskiej ${ }^{23}$.

PIK przekazała projekt ustawy Ministerstwu Kultury i Dziedzictwa Narodowego w dniu 21 października, choć nie uczestniczyło ono w pracach nad ustawą ze względu na ich społeczny charakter. Poparcie dla wprowadzenia regulacji wyraził jednak ówczesny minister Bogdan Zdrojewski. Przygotowywany przez PIK projekt początkowo nie był publicznie dostępny. Został opublikowany dopiero 30 października 2013 roku przez serwis „Dziennik Internautów” po tym, jak otrzymał on go od Centrum Informacji Ministerstwa Kultury i Dziedzictwa Narodowego ${ }^{24}$.

Opublikowany projekt, nazwany „Projektem ustawy o cenie stałej na książki”, zakładał, że ustalona przez wydawcę lub importera cena detaliczna obowiązywałaby przez 18 miesięcy po wprowadzeniu książki na rynek. Cena ta musiałaby zostać przez nich umieszczona na książce oraz w internetowym katalogu. Sprzedawcy mieliby możliwość udzielania rabatów nieprzekraczających $5 \%$ stałej ceny lub $30 \% \mathrm{w}$ przypadku sprzedaży książek na potrzeby bibliotek ${ }^{25}$. Odbiegało to od wcześniejszych założeń, które przewidywały, że projektowana ustawa miałaby dopuszczać stosowanie przez sprzedawców ceny aż o $10-15 \%$ niższej od ceny ustalonej przed wydawcę ${ }^{26}$. W toku dalszych konsultacji branżowych zmianom podlegały także inne założenia ustawy.

25 października 2013, podczas 17. Targów Książki w Krakowie, odbyło się spotkanie PIK z zainteresowanymi środowiskami, podczas którego prowadzono rozmowy nad kształtem projektu ustawy ${ }^{27}$. Zastrzeżenia wzbudziła długość okresu ochronnego. Piotr Marciszuk z Sekcji Wydawców Edukacyjnych PIK postulował wprowadzenie rocznego okresu ze względu na taką długość funkcjonowania na rynku książek edukacyjnych. Sonia Draga reprezentująca Sekcję Wydawców

22 M. Ślusarek, Opinia prawna w sprawie zgodności projektu ustawy o jednolitej cenie ksiązki z prawem Unii Europejskiej, PIK [serwis internetowy], 22.01.2014, s. 3, http://www.pik.org.pl/ upload/files/Opinia___zgodnosc_z_prawem_UE.pdf [dostęp: 20.09.2017].

${ }^{23}$ Idem, Opinia prawna w sprawie zgodności projektu ustawy o jednolitej cenie ksiażki z prawem konstytucyjnym Rzeczypospolitej Polskiej, PIK [serwis internetowy], 22.01.2014, http:// www.pik.org.pl/upload/files/Opinia___zgodnosc_z_prawem_konstytucyjnym_RP.pdf [dostęp: 20.09.2017].

24 M. Maj, Ustawa o książce - ministerstwo kultury nie współtworzy projektu, ale co o nim wie?, Dziennik Internautów [portal], 30.10.2013, http://di.com.pl/ustawa-o-ksiazce-ministerstwo-kultury-nie-wspoltworzy-projektu-ale-co-o-nim-wie-49036 [dostęp: 20.09.2017].

${ }^{25}$ Projekt ustawy o cenie stałej na ksią̇ki, 21.10.2013, https://pl.scribd.com/doc/180164354/ Projekt-PIK-UoK-z-21-10-2013-r-Wersja-17-10-Bez-Komentarzy [dostęp: 20.09.2017].

26 Takie ustalenia przedstawił w maju 2013 roku prezes PIK Włodzimierz Albin — zob. S. Czubkowska, Ksiegarnie chca powrotu do komunizmu, Dziennik Gazeta Prawna [portal], 15.05.2013, http://gospodarka.dziennik.pl/news/artykuly/427606,komunizm-wraca-na-rynek-ksiazek.html [dostęp: 20.09.2017].

27 17. Targi Ksiązki w Krakowie, PIK [serwis internetowy], 16.01.2014, http://www.pik.org. pl/komunikaty/107/17-targi-ksiazki-w-krakowie [dostęp: 20.09.2017]. 
Beletrystycznych PIK twierdziła, że najkorzystniejsze dla rynku książki będzie wprowadzenie jednolitej ceny na 6 miesięcy. Ponadto Henryk Tokarz, prezes Izby Księgarstwa Polskiego, wyraził sprzeciw wobec wysokości dopuszczalnego rabatu dla bibliotek. Jego zdaniem mogłoby to umożliwić sprzedawcom prowadzenie nadmiernej konkurencji cenowej ${ }^{28}$.

12 grudnia 2013 roku odbyło się kolejne spotkanie poświęcone projektowi ustawy. Na nim również poruszono problem rabatu dla bibliotek. Zdaniem uczestników dyskusji możliwość sprzedaży książek z dużym rabatem mogłaby spowodować, że biblioteki nie będą dokonywać zakupów w księgarniach, a bezpośrednio u wydawców i hurtowników, którzy będą w stanie zaoferować tak duże zniżki. Poruszono też kwestię art. 2 ust. 6 pkt 3, zgodnie z którym obowiązek ustalania stałej ceny nie dotyczyłby „książek wydanych na zamówienie, w nakładzie nieprzekraczającym 150 egzemplarzy". Zwrócono uwagę, że umożliwiałoby to ominięcie przepisów o jednolitej cenie poprzez ciągłe dodruki. Zastrzeżenia budził również art. 2 ust. 4: „Wydawca i importer nie mogą oferować sprzedawcom pośrednim gorszych warunków sprzedaży niż sprzedawcom finalnym, których zaopatrują bezpośrednio". Uznano, że w zbyt dużym stopniu sprzyja on sprzedawcom hurtowym i hipermarketom ${ }^{29}$.

PIK oficjalnie przedstawiła przygotowywaną ustawę 20 lutego 2014 roku na konferencji prasowej „Na Ratunek Książkom! Projekt Ustawy o Jednolitej Cenie Książek"30. Porównanie z poprzednią wersją wykazało, że zostały w niej zawarte zmiany, które wypracowano podczas konsultacji branżowych. Skrócono czas obowiązywania jednolitej ceny z 18 do 12 miesięcy i wprowadzono zapis pozwalający wydawcy lub importerowi na ustalenie nowej ceny książki po 6 miesiącach od jej wprowadzenia na rynek, lecz dopiero po uprzednim wycofaniu z rynku całego nakładu. Obniżono także dopuszczalny rabat dla bibliotek do $20 \%$. Ponadto omawiany art. 2 ust. 4 został usunięty.

Zmianie uległ wyjątek, który pozwalał nie wyznaczać ceny dla nakładów nieprzekraczających 150 egzemplarzy. W nowym projekcie sprecyzowano, że jeśli dany tytuł ma zostać wyłączony z przepisów o stałej cenie, jego łączny nakład nie może przekraczać 150 egzemplarzy. Dodatkowo zniesiono obowiązek ustalania stałej ceny dla importowanych książek wydanych przez zagranicznych wydawców, które nie są w języku polskim.

Zrezygnowano z zapisu nakazującego wydawcom i importerom jednoczesne umieszczanie ceny na książce oraz utrzymywanie publicznie dostępnego, internetowego katalogu zawierającego cenę i okres jej obowiązywania. Na jego miejsce

28 Wydawcy postulują wprowadzenie ceny stałej książek, Puls Biznesu [portal], 25.10.2013, https://www.pb.pl/wydawcy-postuluja-wprowadzenie-ceny-stalej-ksiazek-733910 [dostęp: 20.09.2017].

29 M. Staniewicz, Droga do kompromisu, „ZMOWA” 2014, nr 3, s. 3-4, https://issuu.com/ zmowa/docs/gazeta_zmowy_nr_3_2014 [dostęp: 20.09.2017].

30 „,Na ratunek ksiązkom! Projekt ustawy o jednolitej cenie książek”... 
wprowadzono konieczność zastosowania tylko jednego z tych rozwiązań oraz dodatkowy obowiązek informowania Biblioteki Narodowej o cenie książki ${ }^{31}$.

Poza prowadzeniem prac nad przygotowaniem projektu przepisów o stałej cenie PIK podejmowała też kontakty z posłami na Sejm i senatorami w celu uchwalenia ustawy. W ich wyniku 17 marca 2015 roku odbyło się posiedzenie senackiej Komisji Kultury i Środków Przekazu poświęcone proponowanym przez PIK regulacjom ${ }^{32}$. Początkowo propozycja obowiązku stosowania jednolitej ceny książki budziła wątpliwość co do jej zgodności z art. 20 Konstytucji Rzeczypospolitej Polskiej, który gwarantuje w Polsce wolność gospodarczą. Art. 22 zezwala jednak na jej ustawowe ograniczenie, jeśli jest to podyktowane ważnym interesem publicznym. W. Albin wyraził przekonanie, że cel ustawy, jakim jest zachowanie licznych, niezależnych księgarń i stworzenie dostępu do różnorodnej literatury, stanowi wystarczające uzasadnienie do jej wprowadzenia w życie. Po wysłuchaniu opinii zainteresowanych środowisk senatorzy jednogłośnie zdecydowali, że podejmą inicjatywę ustawodawczą w sprawie regulacji rynku książki ${ }^{33}$.

Kolejny projekt został opublikowany przez PIK 25 marca 2015 roku. Jedyną zmianą, którą wprowadzono, był zapis o czasie wejścia przepisów w życie. W poprzednich projektach przyjęto, że całość ustawy zaczęłaby obowiązywać po sześciu miesiącach od ogłoszenia ustawy. Zgodnie z tym projektem wymóg umieszczania informacji o cenie i dacie wprowadzenia do obrotu na książce lub w katalogu wydawcy oraz konieczność informowania Biblioteki Narodowej o ustalonej cenie zaczęłyby obowiązywać już dwa tygodnie po ogłoszeniu ustawy ${ }^{34}$.

Ostatniemu projektowi z 2015 roku nadano tytuł Ustawy o książce. Przywrócono w nim sześciomiesięczny vacatio legis dla całości przygotowywanych przepisów. Była to ostatnia zmiana, którą wprowadzono w treści projektowanej ustawy przed rozpoczęciem procesu legislacyjnego w 2015 roku $^{35}$. Pomimo wcześniejszej decyzji senackiej komisji inicjatywa ustawodawcza została podjęta w Sejmie w trakcie jego VII kadencji. Chęć wprowadzenia regulacji rynku książki wyraził klub poselski Polskiego Stronnictwa Ludowego (PSL), który 8 kwietnia 2015 roku

31 Projekt ustawy o jednolitej cenie ksiązki, PIK [serwis internetowy], 18.02.2014, http:// www.pik.org.pl/upload/files/Projekt_ustawy_jednolita_cena_ksiazki_18_02_2013_3.pdf[dostęp: 20.09.2017].

32 Projekt Ustawy o książce...

33 Zapis stenograficzny. Posiedzenie Komisji Kultury i Środków Przekazu (80.) w dniu 17 marca 2015 r., s. 20, Senat RP [serwis internetowy], http://www.senat.gov.pl/download/gfx/ senat/pl/senatkomisjeposiedzenia/5628/stenogram/080ksp_egz_2.pdf [dostęp: 20.09.2017].

34 Projekt ustawy o jednolitej cenie ksiażki, PIK [serwis internetowy], 25.03.2015, http:// www.pik.org.pl/upload/files/Projekt_ustawy_jednolita_cena_ksiazki_25_03_2015.pdf [dostęp: 20.09.2017].

35 Druk nr 3477, s. 2-8, Sejm RP [serwis internetowy], http://orka.sejm.gov.pl/Druki7ka.nsf /0/9E688B15F19B4EACC1257E600030C321/\%24File/3477.pdf [dostęp: 20.09.2017]. 
złożył na ręce Marszałka Sejmu projekt przygotowany przez PIK. Zgłoszonemu projektowi ustawy został nadany numer druku $3477^{36}$.

Zaproponowane przez PIK przepisy zobowiązywałyby wydawców i importerów do ustalenia cen detalicznych (których wysokość obejmowałaby podatek od towarów i usług) książek, które byłyby stosowane przy sprzedaży detalicznej przez 12 miesięcy ${ }^{37}$ po wprowadzeniu ich do obrotu ${ }^{38}$. Ponadto mieliby obowiązek umieszczania na książce lub w internetowym katalogu ceny i daty wprowadzenia danego tytułu na rynek i przekazania tych informacji Bibliotece Narodowej wraz z egzemplarzem obowiązkowym.

Projekt ustawy pozwalał wydawcom na ustalenie osobnej ceny sprzedaży swoich książek dla prenumeratorów gazet ${ }^{39} \mathrm{i}$ czasopism, których są wydawcami, a także na ustalenie różnych cen dla różnych standardów edytorskich tego samego tytułu, np. dla wydań w twardej lub miękkiej oprawie. Ponadto dopuszczał zmianę ceny ustalonej przez wydawcę lub importera przed zakończeniem okresu ochronnego, lecz dopiero po uprzednim wycofaniu przez nich nakładu z rynku i najwcześniej po 6 miesiącach od rozpoczęcia sprzedaży. Wydania bibliofilskie o numerowanym nakładzie poniżej 500 egzemplarzy, książki wydane na zamówienie w nakładzie, który łącznie nie przekracza 150 egzemplarzy, książki rękodzielnicze oraz książki importowane w języku innym niż język polski zostały wyłączone z przygotowywanych przepisów o stałej cenie.

Do stosowania ceny ustalonej przez wydawcę lub importera zobowiązani byliby wszyscy sprzedawcy końcowi. Ustawa zezwalałaby im na udzielenie rabatu

36 Projekt Ustawy o książce... Indywidualne numery druku są przydzielane każdemu projektowi w celu ich łatwej identyfikacji — zob. Proces ustawodawczy, Sejm RP [serwis internetowy], http://opis.sejm.gov.pl/pl/procesustawodawczy.php [dostęp: 20.09.2017].

37 Pełna treść art. 7 ust. 1 brzmi: „Stosowanie ceny jest obowiązkowe w okresie 12 miesięcy od końca miesiąca, w którym wprowadzono książkę do obrotu" — zob. Druk nr 3477, s. 4. Jak wskazuje autor opinii prawnej z Biura Analiz Sejmowych, pozwala to na interpretację, zgodnie z którą cena jednolita nie obowiązywałaby w pierwszym miesiącu kalendarzowym sprzedaży książki — zob. P. Kościelny, Opinia prawna na temat zgodności z Konstytucją RP regulacji przewidzianych w poselskim projekcie ustawy o ksiażce (druk sejmowy nr 3477), 8.08.2015, s. 2, Sejm $\mathrm{RP}$ [serwis internetowy], http://orka.sejm.gov.pl/RexDomk7.nsf/0/F7F2C440B8AC3C07C1257EA 700275786/\$file/i1846-15.rtf [dostęp: 20.09.2017].

38 Według twórcy projektu ustawy, M. Ślusarka, wprowadzenie do obiegu należy rozumieć zgodnie z definicją zawartą w ustawie z dnia 4 lutego 1994 roku o prawie autorskim i prawach pokrewnych, art. 6 ust. 1 pkt 6: „wprowadzeniem utworu do obrotu jest publiczne udostępnienie jego oryginału albo egzemplarzy drogą przeniesienia ich własności dokonanego przez uprawnionego lub za jego zgodą". Kwestia ta została wyjaśniona dopiero na posiedzeniu sejmowej podkomisji — zob. Podkomisja nadzwyczajna do rozpatrzenia poselskiego projektu ustawy o ksiażce (druk $n r$ 3477), Sejm RP [serwis internetowy], 8.09.2015, http://www.sejm.gov.pl/Sejm7.nsf/transmisje. xsp?unid=857BAFEF1D378529C1257EAD002E1EFD [dostęp: 20.09.2017].

39 Jest to termin użyty w projekcie ustawy, zdaniem sejmowego Biura Legislacyjnego właściwszy byłby termin „dziennik” ze względu na jego obecność w ustawie z dnia 26 stycznia 1984 roku Prawo prasowe - zob. ibidem. 
o maksymalnej wysokości 5\%. Większy rabat mógłby zostać udzielony w szczególnych przypadkach. Dopuszczalny byłby rabat sięgający $20 \%$ przy sprzedaży książek bibliotekom i 15\% w trakcie targów książki nie dłuższych niż 4 dni, w których uczestniczy co najmniej 10 sprzedawców, oraz przy sprzedaży podręczników stowarzyszeniom rodziców uczniów. Obowiązek sprzedaży w jednolitej cenie nie dotyczyłby sprzedaży książki jej wydawcom, importerom, dystrybutorom ${ }^{40} \mathrm{i}$ ich pracownikom, a także autorowi. Sprzedawcy mogliby ustalić inną cenę dla książek, które byłyby „używane, wybrakowane, wadliwe lub uszkodzone”.

Oprócz tego proponowana ustawa nakładała na sprzedawców, których główną działalnością jest sprzedaż książek, obowiązek zamówienia na życzenie klienta książki niedostępnej w danym sklepie, ale dostępnej w ofercie wydawcy lub importera. Kupujący mógłby zostać obciążony kosztami związanymi z dostawą książki, jednak sama usługa złożenia zamówienia powinna zostać udzielona bezpłatnie przez sprzedawcę.

Ustawa nie miałaby zastosowania do ,ponadgranicznego handlu elektronicznego" z wyjątkiem sytuacji, gdy odbiór następuje w punkcie stacjonarnym ustalonym przez zagranicznego sprzedawcę lub gdy magazynuje on książki na terenie Polski i z tego miejsca dokonuje wysyłki do klienta. Aby zapobiec próbom obejścia przepisów ustawy w przypadku eksportu za granicę książki wydanej w Polsce, a następnie jej importu do Polski, ustalono, że w takim przypadku jej cena nie powinna być niższa niż pierwotnie ustalona przez wydawcę. Ponadto zabroniona byłaby sprzedaż towarów i usług z książką dołączoną jako darmowy dodatek lub sprzedaż książki z dołączonymi dodatkami lub usługami, darmowymi lub o zaniżonych cenach, o ile nie było to decyzją wydawcy lub importera, wliczoną w ustaloną przez nich cenę książki.

Całość ustawy weszłaby w życie po sześciu miesiącach od jej ogłoszenia. Twórcy projektu uzasadniali tę długość tym, że dla podmiotów działających na rynku książki konieczny jest czas na przygotowanie się do wprowadzenia nowych przepisów, które stanowią znaczną ingerencję w ich dotychczasowy sposób działania $^{41}$.

Do orzekania w sprawach sądowych o złamanie przepisów ustawy stosowane byłyby przepisy Ustawy z dnia 24 sierpnia 2001 roku - Kodeks postępowania w sprawach o wykroczenia. Za nieprzestrzeganie obowiązków nałożonych przez ustawę na wydawców, importerów oraz sprzedawców przewidziana została kara grzywny ${ }^{42}$. Oprócz tego sprzedaż książki za cenę niezgodną z ustawą o książce

40 Zgodnie z wyjaśnieniem M. Ślusarka jako dystrybutorów należy rozumieć te przedsiębiorstwa, które nie prowadzą działalności sprzedaży końcowej książek, czyli hurtowników — zob. ibidem.

41 Druk nr 3477, s. 2-12.

42 Jej wysokość nie została określona w projekcie, lecz najwyższa możliwa grzywna w polskim prawie wykroczeń to 5 tysięcy zł — zob. Podkomisja nadzwyczajna do rozpatrzenia poselskiego projektu ustawy o książce (druk nr 3477)..., 8.09.2015. 
oraz reklamowanie sprzedaży w cenie niższej niż dopuszczalna przez tę ustawę uznane byłyby za czyny nieuczciwej konkurencji zgodnie ze zmianą wprowadzoną w ustawie z dnia 16 kwietnia 1993 roku o zwalczaniu nieuczciwej konkurencjii ${ }^{43}$.

Zgodnie z art. 3 pkt 3 przez książkę w tekście projektu ustawy rozumie się „publikację objętą symbolem 58.11.1 lub 58.11.2 Polskiej Klasyfikacji Wyrobów i Usług" (PKWiU). W PKWiU z 2008 roku, która obowiązywała w trakcie przygotowywania ustawy, są to „książki drukowane” oraz „książki wydawane na dyskach, taśmach i innych nośnikach". Przepisy o jednolitej cenie mogłyby więc obowiązywać również przy sprzedaży książek elektronicznych oraz audiobooków na nośnikach materialnych, nie dotyczyłyby jednak „książek online" (którym przypisany jest symbol 58.11.3) ${ }^{44}$. Według uzasadnienia twórców projektu zdecydowano się wykorzystać PKWiU, a nie standard ISBN, gdyż pomimo powszechnego wykorzystania ISBN ,nie stanowi bezwzględnej regulacji

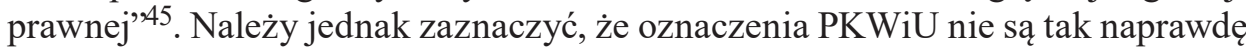
definicją książek, na co w trakcie prac ustawodawczych zwróciło uwagę Biuro Legislacyjne Kancelarii Sejmu (BL), którego zadaniem jest wsparcie prac Sejmu w kwestiach prawnych i ustawodawczych. Przedmiot zaproponowanych regulacji może więc budzić wątpliwości ${ }^{46}$.

Przed rozpoczęciem prac przez posłów nad zgłoszonym projektem BL w swojej wstępnej opinii wyraziło wątpliwość dotyczącą zgodności proponowanych przepisów o jednolitej cenie $\mathrm{z}$ art. 20 Konstytucji RP, który gwarantuje w Polsce swobodę działalności gospodarczej. W odpowiedzi przez wnioskodawców projektu do druku 3477 została dołączona opinia prawna. Stwierdzono w niej, że choć ustawa istotnie naruszałaby swobodę gospodarczą (głównie sprzedawców, w mniejszym stopniu wydawców i importerów), to jej cel realizowałby inne konstytucyjne wartości, takie jak ,stwarzanie warunków upowszechniania i równego dostępu do dóbr kultury" zgodnie z art. 6 ust. 1 Konstytucji. Wskazano, że art. 22 Konstytucji pozwala na ustawowe ograniczenie wolności gospodarczej ze względu na interes publiczny ${ }^{47}$, przy czym musi zostać zachowana zasada proporcjonalności.

43 Druk nr 3477, s. 6-7.

44 Klasyfikacja PKWIU 2008, GUS [serwis internetowy], http://stat.gov.pl/Klasyfikacje/doc/ pkwiu_08/pdf/pkwiu2008.xls [dostęp: 20.09.2017]. PKWiU obowiązuje na mocy rozporządzenia Rady Ministrów i stosowana jest w statystyce, ewidencji i dokumentacji oraz rachunkowości zob. Polska Klasyfikacja Wyrobów i Ustug, GUS [serwis internetowy], http://stat.gov.pl/Klasyfikacje/doc/pkwiu_08 [dostęp: 20.09.2017].

45 Druk nr 3477, s. 10.

46 Podkomisja nadzwyczajna do rozpatrzenia poselskiego projektu ustawy o ksią̇ce (druk nr 3477)..., 8.09.2015.

47 Pojęcie interesu publicznego zostało zdefiniowane w dokumencie jako „wartości oraz stany, które będą się przyczyniały do dobra możliwie dużej liczby ludzi i które zaspokoją interesy 
Zgodnie z zasadą proporcjonalności wprowadzana regulacja powinna spełniać trzy warunki: powinna przynieść oczekiwany efekt (,zasada przydatności”), powinna „być niezbędna dla ochrony interesu publicznego, z którym jest powiązana", przy czym jej skutki nie powinny być możliwe do zrealizowania w inny sposób (,zasada konieczności”), oraz skutki te powinny równoważyć nakładane obciążenia (,zasada proporcjonalności w ścisłym tego słowa znaczeniu”). Spełnienie zasady przydatności przez projekt ustawy o książce nie było przedmiotem analizy ze względu na charakter tego problemu, który wykracza poza kwestie prawne, jednak uznano, że oczekiwania co do pozytywnych skutków ustawy o książce wydają się być uzasadnione. W kwestii zasady konieczności wskazano, że obowiązujące w Polsce przepisy nie chronią książki jako dobra kultury i nie stwarzają warunków dla rozwoju czytelnictwa oraz poszerzania oferty wydawniczej, choć leży to w interesie publicznym i może być osiągnięte przez przewidziane w ustawie ograniczenie swobody gospodarczej. Oprócz tego zwrócono uwagę, że swoboda ta byłaby naruszana przez ustawę w niewielkim stopniu, a proponowane rozwiązanie nie polega na bezpośredniej interwencji państwa w gospodarkę, gdyż w myśl ustawy to nie organy władzy ustalałyby obowiązujące ceny książek, lecz ich wydawcy i importerzy. Odnośnie do zasady proporcjonalności w ścisłym znaczeniu oceniono, że korzyści płynące z przyjęcia przepisów o jednolitej cenie rekompensują nieznaczne ograniczenia nałożone na wydawców, importerów oraz sprzedawców ${ }^{48}$.

24 kwietnia 2015 roku Kancelaria Sejmu wystosowała do Sądu Najwyższego, Krajowej Rady Sądownictwa oraz Prokuratora Generalnego wnioski o ich opinię dotyczącą projektu ustawy. Sąd Najwyższy i Krajowa Rada Sądownictwa nie złożyły uwag, natomiast Prokurator Generalny Andrzej Seremet przedstawił własną ocenę dotyczącą konstytucyjności przepisów o jednolitej cenie książek. Wyraził w niej wątpliwość, czy argumenty dotyczące wspierania kultury, czytelnictwa i księgarń mogą stanowić wystarczające uzasadnienie dla ograniczenia wolności gospodarczej. Stwierdził jednak, że kwestia ta wymaga dalszych rozważań ${ }^{49}$.

9 czerwca 2015 roku projekt został przekazany sejmowej Komisji Kultury i Środków Przekazu. Podczas posiedzenia komisji 5 sierpnia 2015 roku odbyło się jego pierwsze czytanie ${ }^{50}$. W związku z wątpliwościami co do zgodności propono-

i potrzeby jak najszerszego kręgu obywateli, przy równoczesnym wywołaniu zła lub negacji interesu indywidualnego u jak najmniejszego, relatywnie niewielkiego grona osób”.

48 Druk nr 3477, s. 18-32. Nie został podany autor oceny prawnej, lecz tekst pokrywa się z tekstem opinii sporządzonej wcześniej przez M. Ślusarka, twórcę projektu ustawy. Został jednak uzupełniony o ocenę ekonomiczną przygotowaną przez Bibliotekę Analiz — zob. M. Ślusarek, Opinia prawna w sprawie zgodności projektu ustawy o jednolitej cenie książki z prawem konstytucyjnym...

49 Druk nr 3477, s. 35-41.

50 Poselski projekt ustawy o ksiązce, Sejm RP [serwis internetowy], http://www.sejm.gov.pl/ sejm7.nsf/PrzebiegProc.xsp?id=4DBCCBC8E3EF64B0C1257E60003543C8 [dostęp: 20.09.2017]. 
wanych przepisów z Konstytucją i uwagami BL dotyczącymi wad legislacyjnych projektu wymagających dłuższych prac oraz by móc dokładnie zapoznać się z opiniami przedstawicieli rynku książki, podjęto decyzję o utworzeniu nadzwyczajnej podkomisji do spraw ustawy o książce ${ }^{51}$.

Odbyły się cztery posiedzenia podkomisji. Poza jej członkami brali w nich udział reprezentujący wnioskodawców poseł Artur Dębski, prezes PIK W. Albin i twórca projektu ustawy M. Ślusarek oraz przedstawiciele zainteresowanych środowisk, którzy mieli możliwość zgłaszania uwag do projektu, a także przedstawiciele BL, którzy udzielali podkomisji wsparcia w kwestiach prawodawczych.

19 sierpnia 2015 roku miało miejsce pierwsze spotkanie podkomisji, które poświęcono wysłuchaniu opinii o proponowanych regulacjach. Wypowiadający się księgarze, wydawcy oraz autorzy byli zwolennikami ustawy i wyrażali przekonanie, że książka jako dobro kultury nie powinna podlegać nieuregulowanym procesom rynkowym. Piotr Trudnowski, przedstawiciel Klubu Jagiellońskiego $(\mathrm{KJ})^{52}$, oraz Andrzej Faliński z Polskiej Organizacji Handlu i Dystrybucji ${ }^{53}$ zgłaszali jednak wątpliwości odnośnie do przewidywanych przez PIK korzyści ekonomicznych dla rynku książki. Tomasz Makowski, dyrektor Biblioteki Narodowej i przewodniczący Krajowej Rady Bibliotecznej, zwracał uwagę, że ograniczenie

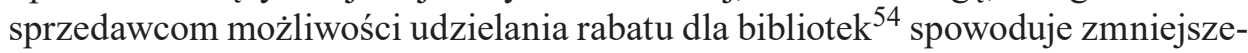
nie liczby kupowanych przez nie nowości wydawniczych i wnioskował o wyłączenie bibliotek z przepisów ustawy ${ }^{55}$.

Przed kolejnym spotkaniem przewodnicząca podkomisji wystąpiła do Biura Analiz Sejmowych (BAS) z prośbą o udzielenie kolejnej opinii dotyczącej zgodności projektu z Konstytucją. Autor analizy stwierdził w niej, że cel ustawy można

$\mathrm{Z}$ reguły wnoszone do Sejmu projekty ustaw są przekazywane odpowiedniej komisji, gdzie odbywa się ich pierwsze czytanie, tj. zapoznanie się z treścią projektu i jego uzasadnieniem. Następnie zostają podjęte prace komisji, która może przyjąć projekt w całości, zgłaszać do niego poprawki lub wnioskować o jego odrzucenie. Po zakończeniu działań komisji na posiedzeniu Sejmu odbywa się drugie czytanie projektu — zob. Poznaj Sejm, Sejm RP [serwis internetowy], http://opis.sejm. gov.pl/pl/procesustawodawczy.php [dostęp: 20.09.2017].

${ }^{51}$ Petny zapis przebiegu posiedzenia Komisji Kultury i Środków Przekazu (nr 196) z dnia 5 sierpnia 2015 r., passim, Sejm RP [serwis internetowy], http://orka.sejm.gov.pl/Zapisy7.nsf/0/EF D0E6E379A0F47FC1257EA8004B4B80/\$file/0499307.pdf [dostęp: 20.09.2017].

52 Stowarzyszenia o charakterze konserwatywnym - zob. O klubie, Klub Jagielloński [serwis internetowy], http://kj.org.pl/o-klubie [dostęp: 20.09.2017].

53 Organizacji zrzeszającej sprzedawców detalicznych i dystrybutorów — zob. Misja i cele organizacji, POHiD [serwis internetowy], http://pohid.pl/o-nas/misja-i-cele-organizacji [dostęp: 20.09.2017].

54 Zgłoszony przez PIK projekt ustawy dopuszczał rabat dla bibliotek nie większy niż 20\%. Jak mówił T. Makowski, rabaty udzielane obecnie przez księgarnie sięgają 40\% ceny detalicznej, a podczas kupna bezpośrednio od wydawców ich wysokość sięga nawet 50\%.

55 Podkomisja nadzwyczajna do rozpatrzenia poselskiego projektu ustawy o książe (druk $n r$ 3477), Sejm RP [serwis internetowy], 19.08.2015, http://www.sejm.gov.pl/sejm7.nsf/transmisje. xsp?unid=22D4CF2B25C5EEC6C1257E99003F4932 [dostęp: 20.09.2017]. 
uznać za służący interesowi publicznemu. Ponadto wskazał, że proponowana ustawa w każdej sytuacji zezwala sprzedawcom na udzielanie rabatu sięgającego 5\% ceny, lub większego w szczególnych przypadkach, a okres ochronny kończyłby się po 12 miesiącach, co łagodzi nakładane na przedsiębiorców obciążenia. Ocenił, że w związku z tym zostałaby zachowana zasada proporcjonalności ${ }^{56}$.

Na posiedzeniu 8 września 2015 roku zgłaszane były propozycje zmian w projekcie, choć na tym etapie nie przyjęto poprawek formalnych. BL wskazało, że brak w projekcie wyjaśnienia terminów „wydawca”, „importer” i „książka”. Stanowiło to istotny problem, od którego zależałby zakres przygotowywanych regulacji. Projekt zawierał definicję książki odwołującą się do symboli z PKWiU (wyróżniających „książki drukowane” i „książki wydawane na dyskach, taśmach i innych nośnikach”), jednak oznaczenia te nie stanowią prawdziwej definicji i budziło wątpliwości, przez kogo oraz na jakich zasadach miałyby być nadawane i weryfikowane. Ponadto PKWiU stanowi załącznik do Rozporządzenia Rady Ministrów, a zgodnie z zasadami legislacji ustawa nie powinna odwoływać się do aktów prawnych niebędących ustawami. Wobec tego pojawiła się wątpliwość, czy ustawa zostanie uznana za zgodną z art. 2 Konstytucji.

Członkowie podkomisji zdecydowali się nie wprowadzać do projektu ustawy oficjalnych zmian, dopóki niezbędne definicje nie zostaną przygotowane przez wnioskodawców projektu. Postanowiono, że zostaną one przyjęte na następnym spotkaniu. Pomimo tego posiedzenie było kontynuowane i omawiano treść poszczególnych artykułów projektu ustawy. Przeprowadzone zostały nieformalne głosowania podkomisji dotyczące tego, które poprawki zostaną poddane pod głosowanie na następnym spotkaniu ${ }^{57}$. Spowodowało to nieporozumienie, gdyż część uczestników posiedzenia uznała, że w wyniku tych głosowań uchwalono przedyskutowane poprawki. Wobec rozbieżności zdań dotyczących aktualnej treści projektu spotkanie komisji 22 września, na którym miały odbyć się formalne głosowania w sprawie wprowadzenia zmian w projekcie, zostało przerwane ${ }^{58}$.

Ostatnie posiedzenie odbyło się 7 października 2015 roku. Przeprowadzone zostały głosowania dotyczące ustalonych wcześniej zmian w projekcie ustawy. Oprócz poprawek merytorycznych wprowadzane były także poprawki natury redakcyjnej.

BL zwróciło uwagę, że nazwa „Ustawa o książce” nie określa precyzyjnie przedmiotu regulacji. Podkomisja zdecydowała się przyjąć tytuł „Ustawa o jednolitej cenie książki”. Do tekstu projektu ustawy zostały też dodane definicje ter-

56 P. Kościelny, op. cit.

57 Podkomisja nadzwyczajna do rozpatrzenia poselskiego projektu ustawy o ksiażce (druk nr 3477)..., 8.09.2015.

58 Podkomisja nadzwyczajna do rozpatrzenia poselskiego projektu ustawy o książce (druk $n r$ 3477), Sejm RP [serwis internetowy], 22.09.2015, http://www.sejm.gov.pl/Sejm7.nsf/transmisje. xsp?unid=460D65A55E050721C1257EC0002C390F [dostęp: 20.09.2017]. 
minów „,importer"59 i ,wydawca" ${ }^{\prime 60}$. Postanowiono jednak, na wzór zagranicznych rozwiązań, nie podejmować się próby definiowania książki.

Nakład książek wydawanych na zamówienie, dla którego niewymagane byłoby ustalenie ceny jednolitej, został obniżony ze 150 do 100 egzemplarzy na wniosek projektodawców. Dozwolony został także rabat w wysokości $20 \%$ dla instytucji kultury i placówek oświaty.

Na wniosek T. Makowskiego komisja zdecydowała się zwolnić sprzedawców z obowiązku stosowania się do stałej ceny podczas sprzedaży książek na użytek bibliotek. Ponadto została przyjęta poprawka nakładająca na wydawców i importerów obowiązek powiadomienia Biblioteki Narodowej o cenie książki oraz zmianie ceny, w oryginalnym projekcie obowiązek ten dotyczył jedynie przekazania wraz z egzemplarzem obowiązkowym informacji o cenie oryginalnej.

Poruszona została również kwestia tego, czy Biblioteka Narodowa byłaby zobowiązana udostępniać zgromadzone informacje o obowiązujących cenach książek, gdyż tekst projektu tego nie precyzuje. Zwracano uwagę, że projekt nie określa, w jaki sposób sprzedawcy końcowi mieliby pozyskiwać informację o cenie książki. W przypadku, dozwolonego przez projekt ustawy, nieumieszczenia ceny na okładce wydawca lub importer miałby obowiązek podać tę informację w katalogu internetowym, jednak nie jest sprecyzowane, co należy rozumieć pod tym pojęciem. Biorący udział w posiedzeniach podkomisji Łukasz Kiczma, przedstawiciel Izby Gospodarki Elektronicznej ${ }^{61}$, stwierdził, że strona internetowa wydawcy nie może pełnić roli pewnego źródła informacji, co miałoby szczególne znaczenie wobec kar przewidzianych dla sprzedawców książek, którzy nie stosowaliby się do stałej ceny ${ }^{62}$. Problem ten jednak nie został rozwiązany ${ }^{63}$.

59 „Należy przez to rozumieć podmiot sprowadzający książkę na terytorium Rzeczypospolitej Polskiej z terytorium państwa członkowskiego Unii Europejskiej (wewnątrzwspólnotowe nabycie) lub z terytorium państwa niebędącego członkiem Unii Europejskiej, w celu wprowadzenia jej do obrotu" - zob. Sprawozdanie podkomisji nadzwyczajnej o poselskim projekcie ustawy o książce (druk $n r$ 3477), s. 1, Sejm RP [serwis internetowy], http://orka.sejm.gov.pl/opinie7.nsf/ nazwa/spr_3477/\$file/spr_3477.pdf [dostęp: 20.09.2017].

60 „Należy przez to rozumieć wydawcę w rozumieniu art. 2 ust. 1 ustawy z dnia 7 listopada 1996 roku o obowiązkowych egzemplarzach bibliotecznych” — zob. ibidem. Definicja, do której odwołuje się tekst projektu, brzmi: „Przez określenie »wydawca« należy rozumieć osobę prawną, jednostkę organizacyjną nie posiadającą osobowości prawnej oraz osobę fizyczną, która prowadzi na obszarze Rzeczypospolitej Polskiej działalność polegającą na publikowaniu dzieł; domniemywa się, że wydawcą jest osoba, której nazwę lub nazwisko uwidoczniono w tym charakterze na egzemplarzach publikacji”.

${ }^{61}$ Izby gospodarczej reprezentującej interesy firm prowadzących działalność typu e-commerce - zob. Misja i cele, Izba Gospodarki Elektronicznej [serwis internetowy], http://www. ecommercepolska.pl/pl/o-nas/misja-i-cele [dostęp: 30.05.2017].

62 Podkomisja nadzwyczajna do rozpatrzenia poselskiego projektu ustawy o książe (druk nr 3477)..., 19.08.2015.

${ }^{63}$ Choć nie zostało to wyjaśnione przez wnioskodawców podczas procesu legislacyjnego, to w założeniach do ustawy przygotowanych w 2010 roku przyjęto, że zasady opracowania katalogu 
Autor analizy prawnej z BAS zwrócił uwagę, że sformułowanie w art. 7 ust. 1 (,[s] tosowanie ceny jest obowiązkowe w okresie 12 miesięcy od końca miesiąca, w którym wprowadzono książkę do obrotu" ${ }^{\prime 4}$ ) tak naprawdę dopuszcza, by jednolita cena książki nie obowiązywała w trakcie pierwszego miesiąca kalendarzowego po rozpoczęciu sprzedaży ${ }^{65}$. Uwaga ta została powtórzona w trakcie posiedzenia komisji sejmowej 8 września ${ }^{66}$. Wnioskodawcy zgodzili się przygotować poprawkę do projektu, jednak nowe brzmienie tego artykułu, które zostało przyjęte 7 października, również wyraźnie pozwala nie stosować się do ceny ustalonej przez wydawcę lub importera (,[j]ednolita cena książki obowiązuje w okresie 12 miesięcy, licząc od pierwszego dnia miesiąca następującego po miesiącu, w którym wprowadzono książkę do obrotu" ${ }^{\prime 67}$ ). Może to być intencją autorów, gdyż kolejna wersja projektu ustawy opublikowana w lutym 2017 roku, o której wprowadzenie przez parlament VIII kadencji zabiega PIK, zawiera podobne sformułowanie (,[j]ednolita cena książki obowiązuje w okresie od daty wprowadzenia książki do obrotu do upływu 12 miesięcy, licząc od pierwszego dnia miesiąca następującego po miesiącu, w którym wprowadzono książkę do obrotu") ${ }^{68}$.

Członkowie podkomisji pracując nad projektem ustawy, mieli świadomość, że prawdopodobnie nie zdąży on zostać przyjęty przez Sejm, gdyż ich ostatnie spotkanie miało miejsce dzień przed ostatnim posiedzeniem Sejmu VII kadencji. Starali się jednak opracować merytorycznie i redakcyjnie tekst ustawy, aby środowiska wydawnicze i księgarskie dysponowały gotowym projektem, który mogłyby przedstawić posłom Sejmu następnej kadencji ${ }^{69}$. Po zakończeniu prac podkomisji tekst projektu ustawy z ustalonymi przez nią poprawkami został przekazany Komisji Kultury i Środków Przekazu ${ }^{70}$. Jej ostatnie posiedzenie miało miejsce następnego dnia, jednak porządek obrad został ustalony wcześniej i temat

i nadzoru nad nim nie powinny być regulowane w ustawie o książce, lecz powinny obowiązywać na mocy odrębnego rozporządzenia Ministra Kultury — zob. Ł. Gołębiewski, K. Frołow, P. Waszczyk, op. cit., s. 126-136.

64 Druk nr 3477, s. 4.

65 P. Kościelny, op. cit., s. 2.

${ }_{66}$ Podkomisja nadzwyczajna do rozpatrzenia poselskiego projektu ustawy o książe (druk nr 3477)..., 8.09.2015.

67 Sprawozdanie podkomisji nadzwyczajnej o poselskim projekcie ustawy o ksiażce (druk $n r$ 3477)...

68 Projekt ustawy ojednolitej cenie ksiażki, PIK [serwis internetowy], 2.02.2017, http://www. pik.org.pl/upload/files/Ustawa\%20o\%20jednolitej\%20cenie $\% 20 \mathrm{ksi} \% \mathrm{C} 4 \% 85 \% \mathrm{C} 5 \%$ BCki_\%20 Projekt\%202017-02-20.pdf [dostęp: 20.09.2017].

69 Podkomisja nadzwyczajna do rozpatrzenia poselskiego projektu ustawy o ksiażce (druk $n r$ 3477)..., 8.09.2015; Podkomisja nadzwyczajna do rozpatrzenia poselskiego projektu ustawy o ksiażce (druk nr 3477), Sejm RP [serwis internetowy], 7.10.2015, http://www.sejm.gov.pl/Sejm7. nsf/transmisje.xsp?unid=FAAB5B21E061BB72C1257ECE003278B3 [dostęp: 20.09.2017].

70 Sprawozdanie podkomisji nadzwyczajnej o poselskim projekcie ustawy o ksiązce (druk $n r 3477) \ldots$ 
ustawy o jednolitej cenie książki nie został na nim poruszony ${ }^{71}$, nie doszło także do drugiego czytania projektu na ostatnim 102. posiedzeniu Sejmu, odbytym 8 i 9 października 2015 roku $^{72}$.

Prowadzone przez PIK i Sejm prace nad projektem ustawy o książce wywoływały szeroką dyskusję społeczną na temat rynku książki i wpływu, jaki miałyby na niego proponowane przepisy. Propozycja nowych przepisów spotkała się z mieszanym odbiorem. Główną obawą dotyczącą skutków regulacji było to, że ograniczenie konkurencji sprzedawców spowoduje wzrost cen książek ${ }^{73}$. Zwolennicy ustawy argumentowali jednak, że skutek regulacji będzie odwrotny i ceny książek spadną. Ich zdaniem obecne ceny są w Polsce zawyżone, za co odpowiedzialna jest praktyka wydawnictw polegająca na ustalaniu wysokiej ceny katalogowej po to, by sprzedawca końcowy mógł obniżyć ją w celach marketingowych, a odebranie możliwości konkurowania ceną sprawi, że cena detaliczna ustalana przez wydawców będzie niższa ${ }^{74}$. W. Albin zapowiedział również, że PIK będzie obserwowała sytuację na rynku wydawniczym i w razie potrzeby zamierza upominać wydawców, którzy chcieliby nadużyć nowego prawa i podnosić ceny ${ }^{75}$.

Przeciwnicy zwracali jednak uwagę, że podwyżki cen powodowane przez uwzględnianie przez wydawców rabatów dla dystrybutorów odnoszą się tylko

${ }^{71}$ Petny zapis przebiegu posiedzenia Komisji Kulturyi Środków Przekazu (nr 198), Sejm RP [serwis internetowy], 8.10.2015, http:/orka.sejm.gov.pl/zapisy7.nsf/0/71EBEA04A972B222C1257 EDE00451623/\%24File/0515707.pdf [dostęp: 20.09.2017].

72 Poselski projekt ustawy o książce...

73 Zob. np. wypowiedzi Mariusza Rutowicza, prezesa sieci księgarskiej Matras, w: J. Bereźnicki, Jednolita cena książki uderzy w rynek. Księgarze ostrzegają, że ceny wzrosna, Money [portal], 10.04.2015, http://www.money.pl/gospodarka/wiadomosci/artykul/jednolita-cena-ksiazki-uderzy-w-rynek,253,0,1758717.html [dostęp: 20.09.2017], publicystki Anny Augustyniak w: eadem, Plusy i minusy ustawy o jednolitej cenie ksiażki, Na Temat [portal], 19.03.2015, http:// annaaugustyniak.natemat.pl/137099,plusy-i-minusy-ustawy-o-jednolitej-cenie-ksiazki [dostęp: 20.09.2017], oraz wydawcy Andrzeja Kuryłowicza i R. Mendrunia w: iidem, Alternatywna wersja ustawy o ksiażce, Portal Księgarski [portal], 17.12.2013, https://www.archiwum.ksiazka.net.pl/index.php?id=126\&tx_ttnews\%5Bpointer\%5D=11\&tx_ttnews\%5Btt_news\%5D $=18516 \& t x \_t$ tnews \%5BbackPid\%5D=125\&cHash=73a5e4b010 [dostęp: 20.09.2017]. Podkomisja nadzwyczajna do rozpatrzenia poselskiego projektu ustawy o ksiażce (druk nr 3477)..., 19.08.2015.

${ }^{74}$ Zob. np. wypowiedź dyrektora Instytutu Książki, Grzegorza Gaudena, w: Zapis stenograficzny. Posiedzenie Komisji Kultury i Środków Przekazu (80.) w dniu 17 marca 2015 r., s. 18, wypowiedź dyrektor generalnej PIK, Grażyny Szarszewskiej, w: eadem, Stałe ceny ksiażek nie oznaczaja wyższych cen. PIK odpowiada na zarzuty czytelników, rozm. przepr. S. Krempa, Granice [portal], http://www.granice.pl/publicystyka,stale-ceny-ksiazek-nie-oznaczaja-wyzszych-cen--pik-odpowiada-na-zarzuty-czytelnikow,782 [dostęp: 20.09.2017], i wypowiedź W. Albina w: idem, Stała cena książki pozwoli obniżyć ceny? Prezes PIK wierzy, że tak będzie, rozm. przepr. M. Maj, Dziennik Internautów [portal], 4.11.2013, http://di.com.pl/stala-cena-ksiazki-pozwoli-obnizyc-ceny-prezes-pik-wierzy-ze-tak-bedzie-wywiad-49051 [dostęp: 20.09.2017].

75 Podkomisja nadzwyczajna do rozpatrzenia poselskiego projektu ustawy o ksiażce (druk nr 3477)..., 19.08.2015.

Roczniki Biblioteczne 61, 2017

(C) for this edition by CNS 
do cen katalogowych, a ceny faktycznie płacone przez klientów są tak naprawdę niższe ${ }^{76}$. Ponadto niektórzy komentatorzy ustawy wskazywali, że choć konkurencja cenowa przy sprzedaży końcowej zostanie ograniczona, to nie jest pewne, czy dystrybutorzy książek i sieci księgarskie przestaną wymagać od wydawców dużych marż, przez co pozycja tradycyjnych księgarń nadal byłaby zagrożona ${ }^{77}$.

Pojawiły się także głosy kwestionujące potrzebę wspierania księgarń za pomocą ustawy. Argumentacja w tym względzie opierała się głównie na twierdzeniu, że Internet zapewnia powszechny i wygodny dostęp zarówno do szerokiej oferty wydawniczej, jak i informacji o niej, zastępując usługi profesjonalnych księgarzy ${ }^{78}$. Podobnie wypowiadał się bibliolog Grzegorz Nieć, którego zdaniem „czas sklepów z książkami się skończył”. Stwierdził, że choć wydawcy i księgarze pełnili istotną rolę w kulturze, to jedynie jako pośrednicy w kontakcie między autorem i odbiorcą, którzy z jego punktu widzenia mają większe znaczenie. Wskazał też, że na przestrzeni wieków sposób produkcji i dystrybucji książek zmieniał się wielokrotnie, a jednolita cena książki stara się ten proces zatrzymać. Oprócz tego zwrócił uwagę, że niekorzystne dla księgarń tradycyjnych zmiany na rynku zachodzą również w tych krajach, w których obowiązuje stała cena ${ }^{79}$.

Część dyskusji na temat ustawy dotyczyła tego, czy dopuszczalna jest ingerencja w swobodę działalności wydawców i sprzedawców książek. Wielu zwolenników regulacji argumentowało, że książka jest szczególnym dobrem kultury,

76 Zob. np. wypowiedź Michała Goszczyńskiego z księgarni internetowej Gandalf w: J. Bereźnicki, op. cit., artykuł dziennikarza Wojciecha Maziarskiego w: idem, Stała cena książki nikomu nie pomoże, Wyborcza [portal], 17.06.2015, http://wyborcza.pl/1,75410,18134383,Stala_cena_ ksiazki_nikomu_nie_pomoze_KOMENTARZ_html [dostęp: 20.09.2017], oraz tekst publicysty i wydawcy Marcina Dobkowskiego w: idem, Ustawa o ksiażce i jej wpływ na rynek księgarni internetowych - analiza i opinia eKomercyjnie.pl, eKomercyjnie [portal], 8.09.2015, http://www. ekomercyjnie.pl/ustawa-o-ksiazce-i-jej-wplyw-na-rynek-ksiegarni-internetowych-analiza-i-opinia [dostęp: 20.09.2017].

77 Zob. np. teksty Anny Gruhn z Instytutu Edukacji Ekonomicznej im. Ludwiga von Misesa w: eadem, Ustawa zwiększyć czytelnictwo, Instytut Misesa [serwis internetowy], 20.04.2015, http:// mises.pl/blog/2015/04/20/gruhnczytelnictwo [dostęp: 20.09.2017], pisarza Tomasza Węckiego w: idem, Ustawa o książce - czego Ci o niej nie mówia, Spisek Pisarzy [portal], 2.05.2015, http:// spisekpisarzy.pl/2015/05/ustawa-o-ksiazce-czego-ci-o-niej-nie-mowia.html [dostęp: 20.09.2017], i publicysty Marcina Zwierzchowskiego w: idem, Co nam da stała cena ksiązki? Raczej niewiele, Lubimy Czytać [portal], 5.03.2015, http://lubimyczytac.pl/aktualnosci/publicystyka/5248/co-nam-da-stala-cena-ksiazki-raczej-niewiele [dostęp: 20.09.2017].

78 Zob. np. M. Dobkowski, op. cit.; A. Gruhn, Cała Polska czyta wydawcom, Instytut Misesa [serwis internetowy], 19.12.2013, http://mises.pl/blog/2013/12/19/gruhn-cala-polska-czyta-wydawcom [dostęp: 20.09.2017].

79 G. Nieć, Przeciw ustawie o statej cenie ksią̇ki, Gazeta Prawna [portal], 8.07.2015, http:// biznes.gazetaprawna.pl/artykuly/881884,przeciw-ustawie-o-stalej-cenie-ksiazki.html [dostęp: 20.09.2017]. 
które nie może być traktowane jak inne produkty handlowe, lecz powinno podlegać szczególnej ochronie ${ }^{80}$. Niektórzy komentatorzy ustawy jednak negatywnie odnosili się do naruszania zasad wolnego rynku przez proponowane przepisy o jednolitej cenie ${ }^{81}$. Zdecydowanie przeciwko ograniczaniu swobody gospodarczej przez projekt PIK wypowiadał się wydawca Andrzej Kuryłowicz ${ }^{82}$. Wystosował list otwarty, w którym sprzeciwiał się zaproponowanej ustawie. Stwierdził w nim ponadto, że PIK nie reprezentuje całego rynku wydawniczego ${ }^{83}$, dlatego nie może nakładać na wszystkich przedsiębiorców regulacji cen ${ }^{84}$. G. Nieć również zwracał uwagę na to, że PIK zrzesza jedynie część podmiotów na polskim rynku książki ${ }^{85}$.

Ponadto propozycja wprowadzenia regulacji rynku książki wzbudziła obawy, że mogłoby to stanowić precedens dla ingerencji państwa w kolejnych dziedzinach gospodarki. W. Albin argumentował jednak, że już wiele sfer życia podlega w Polsce regulacjom i kolejna ustawa nie byłaby czymś wyjątkowym. Stwierdził też, że przepisy zabraniające wydawcom zawierania porozumień z księgarzami o utrzymaniu ceny detalicznej także są pewnym ograniczeniem swobody gospo-

${ }^{80}$ M. Staniewicz, Co nam da stała cena książki?, rozm. przepr. M. Zwierzchowski, Na Ekranie [portal], 23.04.2014, https://naekranie.pl/artykuly/co-nam-da-stala-cena-ksiazki [dostęp: 20.09.2017]; M. Garliński, Ksiązki to nie to samo co bułka, masło i mąka, rozm. przepr. K. Dębek, Forbes [portal], 16.02.2015, http://www.forbes.pl/marcin-garlinski-w-polsce-dokonuje-sie-zbrodni-na-ksiazkach,artykuly,189018,1,1.html [dostęp: 20.09.2017]; G. Gauden, Ustawa o książce, czyli być albo nie być dla Polski, rozm. przepr. R. Pawłowski, Wyborcza [portal], 25.06.2015, http:// wyborcza.pl/1,75410,18244101,Ustawa_o_ksiazce_czyli_byc_albo_nie_byc_dla_Polski.html [dostęp: 20.09.2017].

81 Zob. np. M. Zwierzchowski, op. cit.; M. Dobkowski, op. cit.; P. Podsiedlik, NIE dla ustawy o książce, rozm. przepr. I. Sadowska, Lubimy Czytać [portal], 12.08.2015, http://lubimyczytac.pl/ aktualnosci/rozmowy/5915/nie-dla-ustawy-o-ksiazce-rozmowa-z-piotrem-podsiedlikiem [dostęp: 20.09.2017].

82 S. Czubkowska, op. cit.

83 A. Kuryłowicz podawał przy tym, że liczba polskich wydawnictw sięga kilkunastu tysięcy. Jak twierdzi W. Albin, choć Biblioteka Narodowa rejestruje kilkadziesiąt tysięcy wydawców, to na polskim rynku funkcjonuje znacznie mniej prawdziwych przedsiębiorstw zajmujących się działalnością wydawniczą. Ocenia on, że jest to nie więcej niż 500 podmiotów gospodarczych, lecz udział w rynku większości z nich jest bardzo niewielki, natomiast 150 wydawnictw będących członkami PIK jest, zgodnie z jego szacunkami, odpowiedzialne za $80 \%$ obrotów na rynku wydawniczym - zob. W. Albin, B. Jóźwiak, G. Majerowicz, W interesie całego środowiska, rozm. przepr. P. Waszczyk, Rynek Książki [portal], 31.03.2014, http://rynek-ksiazki.pl/czasopisma/w-interesie-calego-srodowiska [dostęp: 20.09.2017].

84 A. Kuryłowicz, List otwarty w sprawie „Ustawy o ksiażce”, Stowarzyszenie Bibliotekarzy Polskich [serwis internetowy], 22.02.2014, http://www.sbp.pl/artykul?cid=10669 [dostęp: 20.09.2017].

85 G. Nieć, Mówimy NIE stałej cenie książek w tzw. okresie ochronnym, Facebook [portal], 29.04.2015, https://www.facebook.com/niedlaokresuochronnego/posts/172386429623709 [dostęp: 20.09.2017]. 
darczej przedsiębiorców. Gdyby nie obowiązywały, ustawa o książce mogłaby nie być potrzebna wydawcom i księgarzom ${ }^{86}$.

Wobec zakończenia VII kadencji Sejmu do uchwalenia projektowanej ustawy nie doszło. Zgodnie z obowiązującą w Polsce zasadą dyskontynuacji prace legislacyjne przerwane wraz z rozwiązaniem VII kadencji Sejmu nie zostały automatycznie wznowione ${ }^{87}$, lecz kolejny projekt został zgłoszony przez PSL 25 maja $2017 \mathrm{roku}^{88}$. Dalsze losy ustawy znalazły się jednak w zawieszeniu. Choć temat jednolitej ceny był poruszany na spotkaniu Komisji Kultury i Środków Przekazu, które odbyło się 14 września 2017 roku $^{89}$, to nie doszło jeszcze do pierwszego czytania ustawy i prac legislacyjnych. $\mathrm{W}$ jakiejś mierze jest to zapewne efektem znacznych rozbieżności opinii w sprawie zasadności uchwalenia takiej ustawy. Duże znaczenie miały głosy kwestionujące jej pozytywny wpływ na rynek książki, wyrażające obawy co do wzrostu w takim przypadku cen książek oraz podważające potrzebę ratowania tradycyjnych księgarń wobec zachodzących zmian technologicznych. Istotną kwestią stojącą na przeszkodzie uchwaleniu ustawy była i pozostaje nadal zgodność przepisów o jednolitej cenie z Konstytucją RP.

\section{USTAWA Z DNIA ...... A 2015 R. O JEDNOLITEJ CENIE KSIĄŻKI. PROJEKT PRZEGŁOSOWANY PRZEZ PODKOMISJĘ SEJMOWĄ 07.10.2015 R.}

Źródło: Sprawozdanie podkomisji nadzwyczajnej o poselskim projekcie ustawy o książce (druk $n r$ 3477), http://orka.sejm.gov.pl/opinie7.nsf/nazwa/spr 3477/\$file/spr_3477.pdf

Art. 1. Ustawa określa:

1) zasady ustalania jednolitej ceny książki;

2) prawa i obowiązki wydawcy, importera oraz sprzedawcy końcowego związane z dystrybucją książki.

86 Zapis stenograficzny. Posiedzenie Komisji Kultury i Środków Przekazu (80.) w dniu 17 marca 2015 r., s. 6, 18-19.

87 J. Fidala, Wertykalne porozumienia cenowe typu RPM w kontekście rynku ksiązki, „Internetowy Kwartalnik Antymonopolowy i Regulacyjny" 2016, nr 1, s. 8, https://ikar.wz.uw.edu.pl/ numery/32/pdf/00.pdf [dostęp: 22.09.2017].

88 Przebieg procesu legislacyjnego. Druk 1704, Sejm RP [serwis internetowy], http://www. sejm.gov.pl/Sejm8.nsf/PrzebiegProc.xsp?id=2FC69FD61A38E1C2C1258154003231EF [dostęp: 13.10.2017].

89 Petny zapis przebiegu posiedzenia Komisji Kultury i Środków Przekazu (nr 78) z dnia 14 września 2017 r., Sejm RP [serwis internetowy], http://orka.sejm.gov.pl/zapisy8.nsf/0/5D02681 100374209C12581A600485589/\%24File/0224108.pdf [dostęp: 13.10.2017].

A $\mathrm{W}$ tekście pozostawione puste miejsce. 
Art. 2. Przepisów ustawy nie stosuje się do:

1) sprzedaży książki z wykorzystaniem środków komunikacji elektronicznej spoza terytorium Rzeczypospolitej Polskiej na terytorium Rzeczypospolitej Polskiej, chyba że książka jest odbierana przez nabywcę końcowego na terytorium Rzeczypospolitej Polskiej w punkcie odbioru wskazanym przez sprzedawcę końcowego lub wysyłka książki do nabywcy końcowego następuje z terytorium Rzeczypospolitej Polskiej;

2) sprzedaży wysyłkowej książki z terytorium Rzeczypospolitej Polskiej za granicę.

Art. 3. Ilekroć w ustawie jest mowa o:

1) importerze — należy przez to rozumieć podmiot sprowadzający książkę na terytorium Rzeczypospolitej Polskiej z terytorium państwa członkowskiego Unii Europejskiej (wewnątrzwspólnotowe nabycie) lub z terytorium państwa niebędącego członkiem Unii Europejskiej, w celu wprowadzenia jej do obrotu;

2) jednolitej cenie książki — należy przez to rozumieć cenę książki obowiązującą przy jej sprzedaży nabywcy końcowemu, obejmującą stawkę podatku od towarów i usług stosowaną do książek;

3) książce - należy przez to rozumieć książkę wydaną w formie drukowanej lub na dysku, taśmie i innym nośniku;

4) nabywcy końcowym - należy przez to rozumieć podmiot, który nabywa książkę w celach innych niż jej sprzedaż, w szczególności w ramach wykonywanej przez siebie działalności gospodarczej;

5) sprzedawcy końcowym — należy przez to rozumieć podmiot wykonujący działalność gospodarczą w zakresie obrotu książkami, który sprzedaje książkę nabywcy końcowemu;

6) wydawcy — należy przez to rozumieć wydawcę w rozumieniu art. 2 ust. 1 ustawy z dnia 7 listopada 1996 r. o obowiązkowych egzemplarzach bibliotecznych (Dz.U. Nr 152, poz. 722, z późn. zm. ${ }^{\text {B)}) . ~}$

Art. 4. 1. Przed wprowadzeniem książki do obrotu wydawca i importer są obowiązani do ustalenia jednolitej ceny książki.

2. Jednolita cena książki obejmuje wszelkie dodatki sprzedawane wraz z książką i stanowiące jej integralną część, w szczególności nośniki utworów, w tym muzycznych i audiowizualnych.

3. Obowiązek ustalenia jednolitej ceny książki nie ma zastosowania do książki:

1) w wydaniu bibliofilskim, charakteryzującym się wysoką jakością wydania, o przeznaczeniu kolekcjonerskim i wydanej w numerowanym nakładzie nieprzekraczającym 500 egzemplarzy;

B Zmiany wymienionej ustawy zostały ogłoszone w Dz.U. z 2003 r., Nr 130, poz. 1188; z 2008 r., Nr 171, poz. 1056 oraz z 2012 r., poz. 1529. 
2) artystycznej, której wydanie wymagało wykorzystania metod rękodzielniczych;

3) wydanej na zamówienie w łącznym nakładzie nieprzekraczającym 100 egzemplarzy;

4) wydanej poza granicami Rzeczypospolitej Polskiej w języku innym niż język polski i sprowadzonej na terytorium Rzeczypospolitej Polskiej.

Art. 5. 1. Wydawca i importer są obowiązani umieścić trwale na książce lub w internetowym katalogu wydawcy jednolitą cenę książki oraz informację o miesiącu i roku wprowadzenia książki do obrotu.

2. Przed wprowadzeniem książki do obrotu wydawca i importer są obowiązani do przekazania Bibliotece Narodowej informacji o jednolitej cenie książki oraz o zmianach tej ceny.

Art. 6. 1. Jednolita cena książki w ramach subskrypcji lub jednorazowej sprzedaży całej serii lub kolekcji książek oraz wielotomowych encyklopedii i słowników może być różna od sumy jednolitych cen poszczególnych części lub tomów książki.

2. Jeżeli sprzedaż książki nabywcy końcowemu jest dokonywana na raty, łączna kwota rat nie może być niższa od ustalonej uprzednio jednolitej ceny książki.

3. Wydawca i importer są uprawnieni do ustalenia różnych jednolitych cen książki wydanej w różnych standardach edytorskich, w szczególności wydanej w twardej lub miękkiej oprawie.

4. W przypadku sprzedaży książki wydanej przez wydawcę danego dziennika lub czasopisma, wydawca i importer są uprawnieni do ustalenia innej jednolitej ceny książki dla prenumeratorów tego dziennika lub czasopisma.

Art. 7. 1. Jednolita cena książki obowiązuje w okresie 12 miesięcy, licząc od pierwszego dnia miesiąca następującego po miesiącu, w którym wprowadzono książkę do obrotu.

2. Po upływie 6 miesięcy okresu, o którym mowa w ust. 1, wydawca i importer są uprawnieni do wycofania z rynku całego nakładu książki i ustalenia nowej jednolitej ceny książki obowiązującej do końca tego okresu.

3. W przypadku zmiany stawki podatku od towarów i usług stosowanej do książek w okresie, o którym mowa w ust. 1, wydawca i importer są uprawnieni do aktualizacji jednolitej ceny książki uwzględniającej tę zmianę.

4. W przypadku importu lub wewnątrzwspólnotowego nabycia książki wydanej w Rzeczypospolitej Polskiej, a następnie objętej eksportem lub wewnątrzwspólnotową dostawą na terytorium innego państwa jednolita cena książki w okresie, o którym mowa w ust. 1, nie może być niższa niż jednolita cena książki ustalona przez wydawcę.

5. Przepisu ust. 4 nie stosuje się do sprowadzenia książki z państw członkowskich Europejskiego Porozumienia o Wolnym Handlu (EFTA) - stron umowy o Europejskim Obszarze Gospodarczym, chyba że obiektywne czynniki, w szcze- 
gólności brak rzeczywistej sprzedaży książki w tych państwach, pozwalają stwierdzić, że działanie to miało na celu obejście przepisów ustawy.

Art. 8. 1. Do sprzedaży książki po jednolitej cenie książki obowiązany jest sprzedawca końcowy.

2. Sprzedawca końcowy jest obowiązany do sprzedaży książki nabywcy końcowemu po cenie nie niższej niż $95 \%$ i nie wyższej niż $100 \%$ jednolitej ceny książki.

3. Sprzedawca końcowy jest uprawniony do sprzedaży książki po cenie nie niższej niż $85 \%$ i nie wyższej niż 100\% jednolitej ceny książki podczas trwających nie dłużej niż 4 dni targów książki, w czasie których książki do sprzedaży oferuje co najmniej 10 sprzedawców końcowych.

4. Sprzedawca końcowy jest uprawniony do sprzedaży książki po cenie nie niższej niż 85\% i nie wyższej niż 100\% jednolitej ceny książki, jeżeli książką tą jest podręcznik kupowany przez stowarzyszenie rodziców uczniów danej szkoły korzystających z danego podręcznika.

5. Sprzedawca końcowy jest uprawniony do sprzedaży książki po cenie nie niższej niż 80\% i nie wyższej niż 100\% jednolitej ceny książki, jeżeli książka jest nabywana przez:

1) instytucję kultury w rozumieniu przepisów ustawy z dnia 25 października 1991 r. o organizowaniu i prowadzeniu działalności kulturalnej (Dz.U. 2012 r. poz. 406, z 2014 r. poz. 423 oraz z 2015 r. poz. 337);

2) jednostkę organizacyjną, o której mowa $w$ art. 2 ustawy $z$ dnia 7 września 1991 r. o systemie oświaty (Dz.U. z 2004 r. Nr 256, poz. 2572, z późn. zm. ${ }^{C}$ ).

6. Książka używana, wybrakowana, wadliwa lub uszkodzona może być sprzedawana po cenie innej niż jednolita cena książki pod warunkiem poinformowania nabywcy końcowego o wadach danego egzemplarza.

Art. 9. Obowiązek sprzedaży książki po jednolitej cenie książki nie ma zastosowania do jej sprzedaży:

1) wydawcy książki,

2) importerowi książki,

3) przedsiębiorcom wykonującym działalność gospodarczą w zakresie dystrybucji książek,

C Zmiany tekstu jednolitego wymienionej ustawy zostały ogłoszone w Dz.U. 2004 r., Nr 273, poz. 2703 i Nr 281, poz. 2781; z 2005 r., Nr 17, poz. 141, Nr 94, poz. 788, Nr 122, poz. 1020, Nr 131, poz. 1091, Nr 167, poz. 1400 i Nr 249, poz. 2104; z 2006 r., Nr 144, poz. 1043, Nr 208, poz. 1532 i Nr 227, poz. 1658; z 2007 r., $\mathrm{Nr} 42$, poz. 273, Nr 80, poz. 542, Nr 115, poz. 791, Nr 120, poz. 818, $\mathrm{Nr} 180$, poz. 1280 i Nr 181, poz. 1292; z 2008 r., Nr 70, poz. 416, Nr 145, poz. 917, Nr 216, poz. 1370 i $\mathrm{Nr}$ 235, poz. 1618; z 2009 r., $\mathrm{Nr}$ 6, poz. 33, Nr 31, poz. 206, Nr 56, poz. 458, Nr 157, poz. 1241 i Nr 219, poz. 1705; z 2010 r., $\mathrm{Nr} 44$, poz. 250, $\mathrm{Nr}$ 54, poz. 320, $\mathrm{Nr}$ 127, poz. 857 i Nr 148, poz. 991; z 2011 r., $\mathrm{Nr} 106$, poz. 622, $\mathrm{Nr} 112$, poz. 654, $\mathrm{Nr} 139$, poz. 814, $\mathrm{Nr} 149$, poz. 887 i Nr 205, poz. 1206; z 2012 r., poz. 941 i 979; z 2013 r., poz. 87, 827, 1191, 1265, 1317 i 1650; z 2014 r., poz. 7, 290, 538, 598, 642, 811, 1146, 1198 i 1877 oraz z 2015 r., poz. 357, 1045 i 1240. 
4) pracownikom podmiotów, o których mowa w pkt 1-3,

5) autorowi książki,

6) bibliotece w rozumieniu przepisów ustawy z dnia 27 czerwca 1997 r. o bibliotekach (Dz.U. 2012 r. poz. 642 i 908 oraz z 2013 r. poz. 829)

— pod warunkiem zakupu książki na własny użytek.

Art. 10. 1. Jeżeli nabywca końcowy nie ma możliwości zakupu w punkcie sprzedaży książki objętej ofertą handlową wydawcy lub importera, sprzedawca końcowy jest obowiązany, na żądanie nabywcy końcowego i pod warunkiem dostępności książki u wydawcy lub importera, po zapłaceniu przez nabywcę końcowego jednolitej ceny książki, zamówić jeden egzemplarz takiej książki dla nabywcy końcowego. W takim przypadku sprzedawca końcowy jest uprawniony do obciążenia nabywcy końcowego wyłącznie kosztami związanymi z dostarczeniem książki.

2. Przepisu ust. 1 nie stosuje się do punktów sprzedaży, w których znacząca działalność nie polega na sprzedaży książek, w szczególności punktów sprzedaży prasy i sklepów wielobranżowych.

Art. 11. W okresie obowiązywania jednolitej ceny książki zakazane jest w ramach prowadzonej działalności gospodarczej:

1) informowanie o sprzedaży książki po cenie niższej niż jednolita cena książki w punkcie innym niż punkt sprzedaży książki nabywcy końcowemu;

2) oferowanie książki jako bezpłatnego dodatku do produktów lub usług, a także oferowanie produktów lub usług jako dodatków do książki, zarówno bezpłatnych, jak i po cenie znacząco odbiegającej od ceny rynkowej tych produktów lub usług, chyba że sprzedaż tych produktów lub usług łącznie z książką została przewidziana przez wydawcę lub importera i uwzględniona przez te podmioty w jednolitej cenie książki.

Art. 12. Kto:

1) wbrew przepisowi art. 4 ust. 1 nie ustala jednolitej ceny książki,

2) wbrew przepisowi art. 5 ust. 1 nie umieszcza trwale jednolitej ceny książki na książce albo nie zamieszcza jej w internetowym katalogu wydawcy,

3) wbrew przepisowi art. 5 ust. 1 nie umieszcza na książce albo w internetowym katalogu wydawcy informacji o miesiącu i roku wprowadzenia książki do obrotu albo umieszcza informację nieprawdziwą,

4) nie sprzedaje książki po jednolitej cenie książki w okresie, o którym mowa $\mathrm{w}$ art. 7 ust.1,

5) wbrew przepisowi art. 11 pkt 1 informuje o sprzedaży książki po cenie niższej niż jednolita cena książki w punkcie innym niż punkt sprzedaży książki nabywcy końcowemu,

6) wbrew przepisowi art. 11 pkt 2 oferuje książkę jako bezpłatny dodatek do produktów lub usług lub oferuje produkty lub usługi jako dodatki do książki

- podlega karze grzywny. 
Art. 13. Orzekanie w sprawach o czyny, o których mowa w art. 12, następuje w trybie przepisów ustawy z dnia 24 sierpnia 2001 r. - Kodeks postępowania w sprawach o wykroczenia (Dz.U. z 2013 r. poz. 395, z późn. zm. ${ }^{\text {D). }}$

Art. 14. W ustawie z dnia 16 kwietnia 1993 r. o zwalczaniu nieuczciwej konkurencji (Dz.U. z 2003 r. Nr 153, poz. 1503, z późn. zm. E) w art. 3 ust. 2 otrzymuje brzmienie:

„2. Czynami nieuczciwej konkurencji są w szczególności: wprowadzające w błąd oznaczenie przedsiębiorstwa, fałszywe lub oszukańcze oznaczenie pochodzenia geograficznego towarów albo usług, wprowadzające w błąd oznaczenie towarów lub usług, naruszenie tajemnicy przedsiębiorstwa, nakłanianie do rozwiązania lub niewykonania umowy, naśladownictwo produktów, pomawianie lub nieuczciwe zachwalanie, utrudnianie dostępu do rynku, przekupstwo osoby pełniącej funkcję publiczną, a także nieuczciwa lub zakazana reklama, organizowanie systemu sprzedaży lawinowej, prowadzenie lub organizowanie działalności w systemie konsorcyjnym oraz sprzedaż książek po cenie innej niż jednolita cena książki, z naruszeniem przepisów ustawy z dnia ........ o jednolitej cenie książki (Dz.U. poz. ...)".

Art. 15. W ustawie z dnia 7 listopada 1996 r. o obowiązkowych egzemplarzach bibliotecznych (Dz.U. Nr 152, poz. 722 , z późn. zm. ${ }^{\mathrm{F}}$ ) w art. 5 po ust. 1 dodaje się ust. la w brzmieniu:

„1a. Wraz z egzemplarzami obowiązkowymi, o których mowa w ust. 1, Bibliotece Narodowej w Warszawie przekazuje się informację o jednolitej cenie książki w rozumieniu przepisów ustawy z dnia .......... o jednolitej cenie książki (Dz.U. poz. ... ) oraz o zmianach tej ceny".

Art. 16. Przepisy ustawy stosuje się do książki wydanej lub sprowadzonej na terytorium Rzeczypospolitej Polskiej po dniu wejścia w życie ustawy.

Art. 17. Ustawa wchodzi w życie po upływie 6 miesięcy od dnia ogłoszenia.

D Zmiany tekstu jednolitego wymienionej ustawy zostały ogłoszone w Dz.U. z 2013 r., poz. 765 i 1247; z 2014 r., poz. 486, 579, 786 i 969 oraz z 2015 r., poz. 21, 396, 841, 1186 i 1269.

E Zmiany tekstu jednolitego wymienionej ustawy zostały ogłoszone w Dz.U. z 2004 r., Nr 96, poz. 959, Nr 162, poz. 1693, Nr 172, poz. 1804; z 2005 r., Nr 10, poz. 68; z 2007 r., Nr 171, poz. 1206 oraz z 2009 r., Nr 201, poz. 1540.

F Zmiany wymienionej ustawy zostały ogłoszone w Dz.U. z 2003 r., Nr 130, poz. 1188; z 2008 r., Nr 171, poz. 1056 oraz z 2012 r., poz. 1529. 
TOMASZ DZIURDZIA

\section{THE FIXED BOOK PRICE BILL OF 2015}

\section{Summary}

Fixed book prices are applied in some European countries. A fixed book price is the price, set by the publisher, at which the book is to be sold. This solution is to limit price competition among the sellers in order to protect traditional bookshops and promote non-price competition on the book market. In Poland the book market is not regulated in such a way. In 2015 a fixed book price bill, prepared by the Polish Chamber of Books, was submitted to the parliament. However, the bill was not adopted, because the parliament's term ended. The author of the article examines the work of publishers and booksellers on the bill on the basis of the available reports by professionals and journalists, the contents of the bill as well as the course of the legislative process, drawing on records of meetings of parliamentary committees. In addition, the author presents opinions about the bill expressed from early 2013 until late 2015. The opinions come from interviews and articles written by journalists.

KEY WORDS: fixed book price, single book price, Polish Chamber of Books, book market, bookselling, legislation 